\title{
Pengembangan Praktikum Kimia Dasar berbasis Video pada Materi Sistem Periodik Unsur
}

\section{The Development of Basic Chemistry Practicum based on Video on the Topic of Periodic Table System}

\author{
Z Muchtar ${ }^{1}$, S Rahmah ${ }^{1}$, F Harahap ${ }^{1 *}$, C Kurniawan ${ }^{1}$, N Ulfa ${ }^{1}$, F Hasniyah', \\ F A Chaniago ${ }^{1}$, M Fadhilah ${ }^{1}$, J L Sihombing ${ }^{1}$, M Zubir ${ }^{1}$, S A Sari ${ }^{1}$ \\ ${ }^{1}$ Fakultas Matematika dan Ilmu Pengetahuan Alam Universitas Negeri Medan, \\ Jl. Willem Iskandar Psr V Medan Estate, Medan, Sumatera Utara, Indonesia. 20221. \\ *fauziyahharahap@unimed.ac.id
}

\section{ARTICLE INFO \\ Received on: \\ 23 November 2021 \\ Revised till: \\ 22 January 2022}

\section{Accepted on:}

24 January 2022

\section{Publisher version} published on:

15 February 2022

\begin{abstract}
Technological developments change the researchers and educators thinking towards online learning. Various innovations were carried out to support effective online learning which suitable with the student's competencies. As there is urgency for carrying practicum activities to achieved Course Learning Achievement (Capaian Pembelajaran Mata Kuliah (CPMK)) for the basic chemistry subject, there is need to make some innovation, which is by making practicum video. It could stimulate students' critical thinking because it was presented with visual representations. It could overcome the limitations of space and time and could be used repeatedly. The research type was Research and Development with the Borg and Gall development model. The final product will be disseminated through YouTube platform which is integrated with sipda.unimed.ac.id. Validation results in media design and material aspect showed that the product was declared very valid with an average value of $86.87 \%$ and $97.92 \%$, respectively. Meanwhile, the responses from 30 students showed that the product was very practical with an average score of $>90 \%$ and was suitable with learning objectives of the basic chemistry course especially the periodic system of elements.
\end{abstract}

\section{KEYWORDS}

Basic Chemistry, Periodic Table of Elements, Practical Video

\begin{abstract}
ABSTRAK
Perkembangan teknologi mengubah arah berpikir peneliti dan pendidik ke arah pembelajaran daring. Berbagai inovasi dilakukan untuk mendukung pembelajaran daring semakin efektif dan sesuai dengan kompetensi yang dibutuhkan oleh peserta didik. Kebutuhan yang mendesak terhadap pelaksanaan kegiatan praktikum demi tercapainya target Capaian Pembelajaran Mata Kuliah (CPMK) Kimia Dasar dilakukan inovasi berupa pengembangan video praktikum kimia dasar dengan topik sistem periodik unsur. Keunggulan video praktikum dapat merangsang berpikir kritis mahasiswa karena disajikan dengan representasi visual. Video praktikum dapat mengatasi keterbatasan ruang dan waktu serta penggunaannya dapat dilakukan berulang-ulang. Jenis penelitian ini adalah Research and Development (R\&D) dengan model pengembangan Borg and Gall. Produk final kemudian didiseminasikan melalui platform YouTube yang terintegrasi dengan LMS sipda.unimed.ac.id. Hasil validasi desain media dan materi menunjukkan bahwa praktikum kimia dasar berbasis video pada topik sistem periodik unsur dinyatakan sangat valid dengan rata-rata nilai 86,87\% dan 97,92\%. Sedangkan respons dari 30 mahasiswa menunjukkan bahwa video yang dikembangkan sangat praktis dengan ratarata skor $>90 \%$ dan telah sesuai dengan kebutuhan serta tujuan pembelajaran pada mata kuliah kimia dasar materi sistem periodik unsur.
\end{abstract}

KATA KUNCI

Kimia Dasar, Sistem Periodik Unsur, Video Praktikum 


\section{PENDAHULUAN}

Perkembangan teknologi dan internet yang sangat cepat saat ini menuntut para pendidik dan peneliti bidang pendidikan untuk terampil memanfaatkan teknologi dalam pembelajaran ${ }^{[1]}$. Pelaksanaan pembelajaran telah terintegrasi dengan teknologi, yaitu dengan memanfaatkan Learning Management System (LMS) diantaranya Moodle, Wiki dan Edmodo ${ }^{[2]}$. Melalui LMS materi pembelajaran dapat diakses oleh peserta didik dari mana saja dengan menggunakan koneksi internet.

Penyediaan media dan metode pendidikan yang dinamis, kondusif dan dialogis diperlukan untuk pengembangan potensi peserta didik secara optimal. Hal ini dikarenakan potensi siswa jika dibantu dengan sejumlah media atau sarana dan prasarana dapat mendukung proses interaksi yang sedang dilakukan sehingga pembelajaran menjadi lebih efektif ${ }^{[3]}$. Hal ini juga diperlukan pada pembelajaran yang membutuhkan pengujian teori melalui eksperimen. Saat ini banyak media teknologi sedang dikembangkan untuk dapat memaksimalkan proses pembelajaran teori maupun eksperimen secara digital ${ }^{[4]}$.

Sebuah penelitian menunjukkan terjadi peningkatan hasil belajar IPA-Fisika bagi siswa SMP yang diberikan pembelajaran praktikum berbasis media video. Melalui media video, siswa mempelajari hal abstrak dalam wujud nyata sehingga lebih mudah dipahami karena telah tergambarkan dengan jelas dalam video. Selain itu, pembelajaran praktikum menggunakan media video dapat dilakukan dimana saja tidak lagi bergantung pada kegiatan di ruang Laboratorium ${ }^{[5]}$.

Kegiatan di laboratorium dilakukan untuk membuktikan sebuah konsep atau fenomena melalui percobaan ${ }^{[6]}$. Laboratorium adalah sarana bagi peserta didik untuk melakukan praktik kerja ilmiah dan merupakan pendukung dalam memahami konsep-konsep berupa teori. Salah satu metode untuk meningkatkan pemahaman konsep tersebut adalah melalui kegiatan praktikum ${ }^{[7]}$.

Kegiatan praktikum merupakan kegiatan wajib bagi mahasiswa jurusan kimia. Kegiatan praktikum bertujuan untuk memberikan pemahaman kepada mahasiswa tidak hanya teori namun konsep kimia yang lebih realistis dan menarik. Selain itu, kegiatan praktikum juga menumbuhkan kemampuan "practical skill" mahasiswa ${ }^{[8]}$. Kegiatan praktikum umumnya diawali dengan pre-test dan diakhiri dengan post-test. Pre-test adalah sebuah ujian pemahaman mahasiswa terkait kegiatan praktikum yang akan dilakukan, sedangkan post-test adalah evaluasi hasil dari pelaksanaan kegiatan praktikum ${ }^{[2]}$.

Selama pembelajaran daring, praktikum kimia tidak dapat dilakukan secara langsung di Laboratorium Kimia Jurusan Kimia FMIPA Universitas Negeri Medan. Oleh karena itu dibutuhkan berbagai inovasi untuk mendukung tercapainya Capaian Pembelajaran Mata Kuliah (CPMK) pada berbagai mata kuliah di Jurusan Kimia, khususnya kimia dasar. Inovasi yang dapat dilakukan diantaranya penerapan pembelajaran berbasis Project Based Learning ataupun pengembangan media video praktikum di laboratorium ${ }^{[9]}$.

Video praktikum di laboratorium merupakan salah satu inovasi pengembangan kegiatan praktikum jarak jauh. Keunggulan video adalah meningkatkan minat pembelajaran peserta didik karena penyampaian materi dilakukan tidak hanya secara verbal namun juga non verbal (visual) $^{[10]}$. Pembelajaran melalui video juga mampu meningkatkan berpikir kritis mahasiswa. Selain itu, video juga mampu menampilkan fenomena yang sulit ditampilkan secara nyata serta dapat digunakan berulang-ulang sesuai kebutuhan. Keunggulan lainnya adalah pembelajaran praktikum melalui video dapat mengatasi keterbatasan ruang dan waktu ${ }^{[11]}$.

Penelitian ini bertujuan mengembangkan praktikum kimia dasar berbasis video pada topik sistem periodik unsur. Produk video praktikum yang dikembangkan berbeda dengan video yang telah disebarkan melalui platform YouTube. Konten video disesuaikan dengan kebutuhan di Jurusan Kimia FMIPA Universitas Negeri Medan disertai dengan instrumen pendukung sesuai dengan kompetensi yang ingin dicapai.

Penelitian terdahulu menunjukkan adanya peningkatan hasil belajar siswa pada materi stoikiometri yang diajarkan menggunakan video praktikum yang disertai dengan modul elektronik ${ }^{[12]}$. Selain itu, peneliti lain juga mengatakan bahwa terjadi peningkatan hasil belajar siswa pada materi larutan asam basa yaitu siswa mampu menyelesaikan soal-soal pemecahan masalah ${ }^{[13]}$. Melalui video praktikum terjadi peningkatan hasil belajar siswa sehingga sangat cocok digunakan dalam kegiatan pembelajaran daring maupun luring ${ }^{[14]}$.

Pada penelitian ini dikembangkan praktikum kimia dasar berbasis video pada topik sistem periodik unsur. Produk final kemudian didiseminasikan melalui YouTube yang kemudian terhubung dengan Learning Management System (LMS) sipda.unimed.ac.id.

\section{METODE}

Penelitian ini dilakukan di Jurusan Kimia Universitas Negeri Medan. Jenis penelitian ini adalah Research and Development (R\&D). Produk yang dihasilkan adalah video praktikum, lembar prosedur praktikum, lembar soal pilihan berganda, essay dan uraian serta lembar pengamatan praktikum.

Penelitianinimengadopsimodel pengembangan Borg and Gall yang terdiri dari 10 tahapan yaitu (1) penelitian dan pengumpulan informasi, (2) perencanaan, (3) pengembangan produk awal, (4) uji tahap awal (validasi), (5) revisi produk utama, (6) uji respons mahasiswa (kepraktisan), (7) revisi produk operasional, (8) uji lapangan, (9) produk akhir, serta (10) penyebaran dan implementasi ${ }^{[15]}$. Akan tetapi, pada penelitian ini uji lapangan untuk mengetahui pengaruh produk yang dikembangkan terhadap hasil belajar mahasiswa belum dilakukan sehingga perlu adanya penelitian lanjutan (Gambar 1). 


\section{Diagram Alir \\ Pengembangan Praktikum Kimia Dasar \\ Berbasis Video Dasar \\ Berdasarkan Borg and Gall}

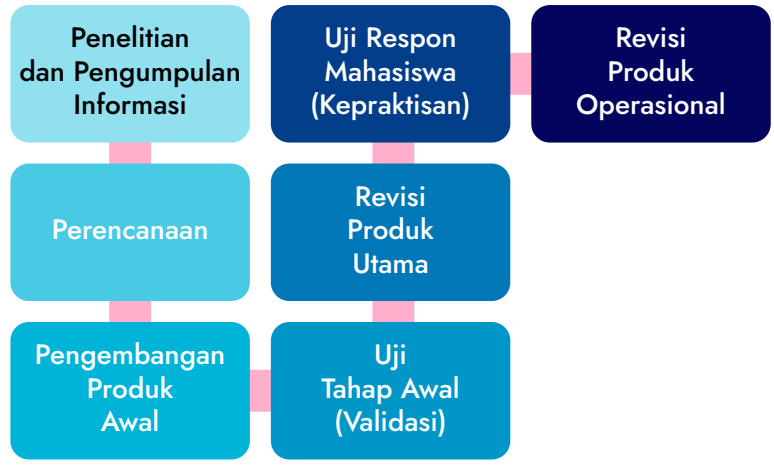

Gambar 1. Diagram alir pengembangan praktikum kimia dasar berbasis video berdasarkan Borg and Gall.

Metode pengumpulan data yaitu menggunakan instrumen berupa lembar validasi yang disusun berdasarkan BSNP dengan skala likert 4 jawaban serta lembar respons mahasiswa yang disusun menggunakan skala likert 5 jawaban. Interpretasi kelayakan produk praktikum kimia dasar berbasis video didasarkan oleh Tabel 1 dan Tabel 4.

\section{HASIL DAN DISKUSI}

Penelitianinimengadopsimodel pengembangan prosedural Borg and Gall, yaitu sebuah proses untuk mengembangkan dan memvalidasi produk pendidikan. Terdapat 10 tahapan yang dikemukakan oleh Borg and Gall, namun, artikel ini hanya membahas 7 dari 10 tahapan tersebut.

\subsection{Penelitian dan Pengumpulan Informasi}

Kimia Dasar adalah mata kuliah wajib bagi mahasiswa jurusan kimia. Sebuah mata kuliah pondasi untuk memahami konsep-konsep dasar kimia. Mata kuliah ini terdiri dari 3 SKS dengan rincian 2 SKS teori dan 1 SKS praktikum. Praktikum kimia dasar bertujuan untuk mengembangkan keterampilan proses yaitu keterampilan dasar dan keterampilan terintegrasi. Kedua keterampilan ini sangat penting yaitu meliputi pengamatan, pengukuran, kemampuan menyusun hipotesis, mengumpulkan, mengelompokkan, mencatat dan menafsirkan data, serta kemampuan mengendalikan variabel.

Kegiatan praktikum biasanya dilakukan di sebuah tempat khusus yang disebut Laboratorium. Laboratorium adalah tempat untuk melakukan penelitian, pengamatan dan pengujian ilmiah. Namun, sejak dikeluarkannya surat edaran Menteri Pendidikan No 4 tahun 2020 dan No 15 tahun 2020 tentangpedoman pelaksanaan pendidikan pada masa darurat Covid-19, praktikum tidak lagi dilakukan di Laboratorium melainkan harus dilaksanakan secara daring. Oleh karena itu, perlu dikembangkan media praktikum kimia dasar yang dapat diakses kapan saja dan dimana saja oleh mahasiswa Jurusan Kimia FMIPA UNIMED. Sehingga, Capaian Pembelajaran
Mata Kuliah (CPMK) kimia dasar dapat tercapai sesuai dengan indikator yang telah tercantum di dalam Rancangan Perkuliahan Semester (RPS).

Praktikum kimia dasar berbasis video dipilih karena berdasarkan kajian pustaka diketahui bahwa melalui tayangan gambar mahasiswa dapat mengenal dan memahami alat dan bahan serta cara penggunaannya pada percobaan kimia $^{[16]}$. Mahasiswa juga mampu menganalisis berbagai fenomena yang telah divisualisasikan melalui video seperti terjadinya perubahan warna, munculnya endapan, adanya gas dan lain-lain. Selain itu, pertanyaan pendukung diperlukan untuk memicu kemampuan berpikir kritis mahasiswa sehingga mampu memecahkan permasalahan yang diberikan ${ }^{[11]}$.

\subsection{Perencanaan}

Perencanaan pengembangan praktikum kimia dasar berbasis video diawali dengan pemilihan topik pada mata kuliah kimia dasar. Sistem periodik unsur merupakan topik yang penting, mencakup konsep pengenalan terhadap unsur-unsur yang telah ditemukan dan dirangkum dalam sebuah tabel periodik. Selain itu, diperlukan pemahaman terhadap sifat fisika dan kimia dari masing-masing unsur hingga kemampuan menganalisis reaksi yang terjadi serta aplikasi unsur pada kehidupan seharihari. Kemampuan ini penting karena ilmu kimia merupakan konsep yang abstrak dan membutuhkan analisa tingkat tinggi ${ }^{[17]}$.

Prosedur praktikum disesuaikan dengan buku penuntun praktikum kimia dasar yang telah dikembangkan oleh tim dosen kimia Jurusan Kimia FMIPA UNIMED. Prosedur kemudian dianalisis dan dijadikan dasar dalam pembuatan storyboard produk Video Praktikum yang akan dikembangkan. Selain itu, disusun perencanaan pembuatan instrumen pendukung seperti soal-soal pemantik untuk memicu kemampuan berpikir kritis mahasiswa. Soal direncanakan dalam tiga bentuk yaitu soal pilihan berganda, essay dan uraian. Masing-masing item pada soal merujuk pada alat, bahan dan prosedur praktikum serta hasil dari pengamatan percobaan.

Lembar pengamatan hasil percobaan dikembangkan dengan mengikuti tahapan-tahapan pada prosedur. Lembar pengamatan ini sebagai dasar bagi mahasiswa untuk melakukan pengamatan secara menyeluruh terhadap tangkapan layar dari praktikum kimia dasar berbasis video.

\subsection{Pengembangan Produk Awal}

Praktikum kimia dasar berbasis video adalah sebuah alternatif pembelajaran praktikum jarak jauh. Dengan memvisualisasikan kegiatan praktikum kimia dasar secara nyata melalui video rekaman diharapkan keterampilan proses mahasiswa tetap terbangun meskipun mahasiswa tidak melakukan kegiatan praktikum secara langsung di Laboratorium.

Berdasarkan perencanaan storyboard pengembangan produk diawali dengan pengambilan video alat dan bahan dan diikuti dengan langkah-langkah percobaan sesuai prosedur percobaan pada topik sistem periodik 
unsur. Kegiatan ini dilakukan di laboratorium kimia dasar Jurusan Kimia FMIPA UNIMED.

Hasil pengambilan video kemudian dikompilasi dan diedit menggunakan aplikasi Capcut dengan menambahkan keterangan pada setiap alat dan bahan serta setiap tahapan-tahapan prosedur yang digunakan. Keterangan ini membantu mahasiswa mengenali fungsi peralatan dan bahan serta peristiwa yang terjadi selama percobaan berlangsung. Hasil produk ini disebut sebagai PKDV versi-1.

\subsection{Uji Tahap Awal (Validasi)}

Pada tahap ini pengujian (uji validasi) produk PKDV versi-1 dilakukan oleh 3 orang validator yaitu dosen jurusan kimia FMIPA Universitas Negeri Medan. Penentuan validator didasarkan pada keahlian yang bersesuaian dengan produk yang diuji. Validasi dibagi menjadi 2 aspek yaitu aspek desain media dan aspek materi. Kedua jenis validasi ini diuji oleh validator yang sama.

Berdasarkan analisis skala likert menggunakan rumus pada Persamaan 1, dimana skor maksimum ialah skor tertinggi tiap item " $x$ " jumlah pertanyaan validasi. Dari Persamaan 1, kemudian dapat diinterpretasikan bahwa produk PKDV versi-1 dinyatakan valid jika memenuhi kriteria sesuai Tabel 1 .

$$
P(\%)=\frac{\sum \text { skor hasil pengambilan data }}{\text { skor maksimum }} \times 100 \% \ldots \text { Persamaan } 1
$$

Tabel 1. Interpretasi Kriteria Validasi ${ }^{[18]}$.

\begin{tabular}{c|c} 
Persentase (\%) & Kategori \\
\hline $0 \leqslant x \leqslant 20$ & Sangat Kurang Valid \\
\hline $21 \leqslant x \leqslant 40$ & Kurang Valid \\
\hline $41 \leqslant x \leqslant 60$ & Cukup Valid \\
\hline $61 \leqslant x \leqslant 80$ & Valid \\
\hline $81 \leqslant x \leqslant 100$ & Sangat Valid \\
\hline
\end{tabular}

Tabel 2. Hasil Validasi Desain Media.

\begin{tabular}{|c|c|c|c|c|}
\hline \multirow{2}{*}{$\begin{array}{l}\text { Vali- } \\
\text { dator }\end{array}$} & \multicolumn{2}{|c|}{ \% Aspek Validitas } & \multirow{2}{*}{$\begin{array}{c}\text { Rata- } \\
\text { rata } \\
\text { (\%) }\end{array}$} & \multirow[b]{2}{*}{ Kategori } \\
\hline & $\begin{array}{c}\text { Penya- } \\
\text { jian }\end{array}$ & $\begin{array}{c}\text { Tampi- } \\
\text { lan }\end{array}$ & & \\
\hline 1 & 75,00 & 80,00 & 77,50 & Valid \\
\hline 2 & 95,83 & 95,00 & 95,42 & $\begin{array}{l}\text { Sangat } \\
\text { Valid }\end{array}$ \\
\hline 3 & 85,42 & 90,00 & 87,71 & $\begin{array}{l}\text { Sangat } \\
\text { Valid }\end{array}$ \\
\hline \multicolumn{3}{|c|}{ Rata-rata (\%) } & 86,87 & $\begin{array}{c}\text { Sangat } \\
\text { Valid }\end{array}$ \\
\hline
\end{tabular}

Hasil analisis perhitungan hasil validasi oleh 3 orang validator menunjukkan bahwa validasi desain media dan materi keduanya sangat valid dengan skor rata-rata $86,87 \%$ dan $97,92 \%$ sesuai dengan Tabel 2 dan Tabel 3.
Tabel 3. Hasil Validasi Materi.

\begin{tabular}{c|c|c} 
Validator & \% Validitas & Kategori \\
\hline 1 & 100,00 & Sangat Valid \\
\hline 2 & 96,88 & Sangat Valid \\
\hline 3 & 96,88 & Sangat Valid \\
\hline Rata-rata (\%) & $\mathbf{9 7 , 9 2}$ & Sangat Valid \\
\hline
\end{tabular}

Berdasarkan analisis tersebut disimpulkan bahwa produk PKDV versi-1 yang dikembangkan sangat valid. Namun, meskipun demikian perlu dilakukan revisi untuk menyempurnakan produk yang dikembangkan sesuai dengan saran validator.

\subsection{Revisi Produk Utama}

Revisi dilakukan pada bagian editing sesuai dengan informasi (saran) yang diberikan oleh validator. Validator menyarankan untuk mengganti musik pengiring agar lebih menarik. Tujuan dari revisi ini adalah untuk menyempurnakan produk sehingga diperoleh produk PKDV versi-2. Kemudian PKDV versi-2 digunakan untuk tahap pengujian kepraktisan terhadap respons mahasiswa pengguna.

\subsection{Uji Respons Mahasiswa (Kepraktisan)}

Respons mahasiswa merupakan bagian dari uji kepraktisan dengan pengambilan data menggunakan angket berskala likert 5 dengan interpretasi sesuai Tabel 4.

Tabel 4. Interpretasi Kriteria Kepraktisan ${ }^{[19]}$.

\begin{tabular}{c|c} 
Persentase (\%) & Kategori \\
\hline $0 \leqslant x \leqslant 20$ & Sangat Kurang Praktis \\
\hline $21 \leqslant x \leqslant 40$ & Kurang Praktis \\
\hline $41 \leqslant x \leqslant 60$ & Cukup Praktis \\
\hline $61 \leqslant x \leqslant 80$ & Praktis \\
\hline $81 \leqslant x \leqslant 100$ & Sangat Praktis
\end{tabular}

Pengujian terhadap respons 30 mahasiswa Jurusan Kimia FMIPA Universitas Negeri Medan melalui 6 pertanyaan yaitu Q1: Media praktikum kimia dasar berbasis video sesuai dengan kebutuhan mahasiswa pada mata kuliah kimia dasar; Q2: Media praktikum kimia dasar berbasis video memudahkan mahasiswa dalam mencapai tujuan pembelajaran; Q3: Media praktikum kimia dasar berbasis video sesuai dengan materi teori yang disajikan; Q4: Media praktikum kimia dasar berbasis video memudahkan mahasiswa mengaplikasikan teori yang disajikan; Q5: Materi dan kegiatan praktikum kimia dasar berbasis video disajikan dengan jelas; Q6: Kualitas tampilan media praktikum kimia dasar berbasis video telah baik. 


\section{Grafik Respon Mahasiswa}

Jenis

Persentase

Pertanyaan (\%)

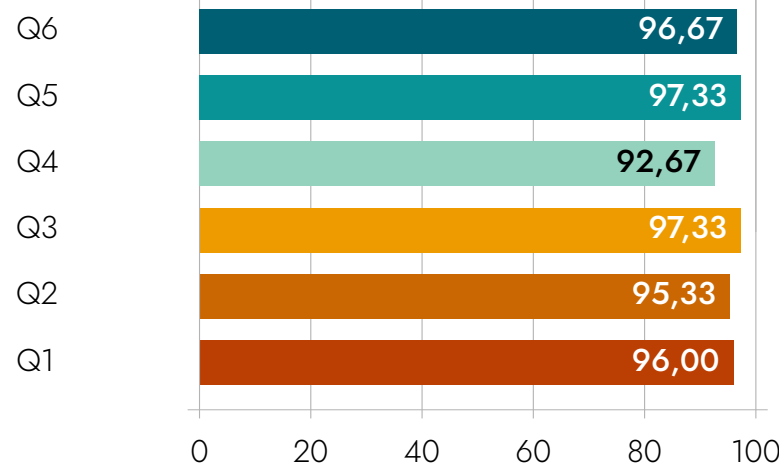

Gambar 2. Grafik Respons Mahasiswa.

Hasil perhitungan respons mahasiswa pada setiap butir pertanyaan (Gambar 2) diketahui bahwa rata-rata dari 30 respons mahasiswa menunjukkan persentase skor di atas $90 \%$. Persentase tersebut dinyatakan sangat praktis berdasarkan interpretasi kriteria pada Tabel 4. Selain itu, berdasarkan analisis respons mahasiswa secara deskriptif diketahui bahwa produk PKDV versi-2 ini sangat bagus dan membuat mahasiswa semakin antusias dan diharapkan ke depannya lebih banyak dikembangkan produk serupa dengan praktikum yang berbeda.

\subsection{Revisi Produk Operasional}

Produk PKDV versi-3 merupakan hasil penyempurnaan setelah mendapatkan respons mahasiswa. Tampilan layar pembukaan video berisi judul praktikum ditunjukkan pada Gambar 3. Konten visualisasi dimulai dari judul, tujuan praktikum, pengenalan alat dan bahan dan tahapan-tahapan percobaan dan diakhiri dengan kredit tim pengembang produk.

Gambar 4 menunjukkan tampilan layar alat dan bahan yang digunakan pada percobaan dengan judul sistem periodik unsur. Sebelum alat dan bahan dirangkum terlebih dahulu divisualisasikan satu persatu disertai petunjuk cara penggunaan beberapa alat yang dianggap penting pada percobaan ini.

Isi konten video memperlihatkan asisten laboratorium bekerja melakukan kegiatan praktikum secara nyata di Laboratorium Kimia Dasar Jurusan Kimia FMIPA UNIMED sesuai dengan prosedur praktikum pada topik sistem periodik unsur. Kegiatan praktikum dijalankan sesuai aturan praktikum pada laboratorium kimia dasar yang melibatkan penggunaan peralatan safety lab seperti jas praktikum dan penggunaan peralatan gelas dan bahan-bahan kimia di laboratorium. Kegiatan praktikum ini bertujuan memberikan pemahaman konseptual kepada mahasiswa serta pemahaman kognitif dan practical skill yang meliputi kemampuan mengamati, mengumpulkan data, analisis data, interpretasi hasil pengamatan, dan pemecahan masalah $^{[16]}$. Gambar 5 dan Gambar 6 menunjukkan tahapan mengamati hasil percobaan pada sub-topik 1 (logam alkali) dan sub-topik 2 (logam alkali tanah).

Untuk mendukung kesempurnaan produk dikembangkan material pendukung berupa soalsoal pilihan berganda, essay dan uraian. Soal yang dikembangkan merujuk pada setiap gerakan percobaan yang divisualisasikan dalam video. Mahasiswa tidak akan bisa menjawab pertanyaan jika tidak mengamati percobaan pada video. Sehingga keterampilan proses meliputi aspek psikomotorik, aspek kognitif dan aspek afektif mahasiswa benar-benar dapat dicapai melalui media PKDV versi-3 ini $^{[20]}$.

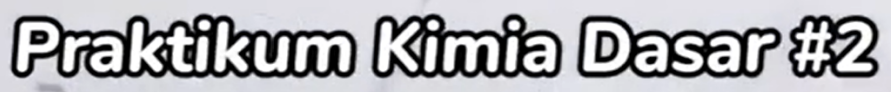

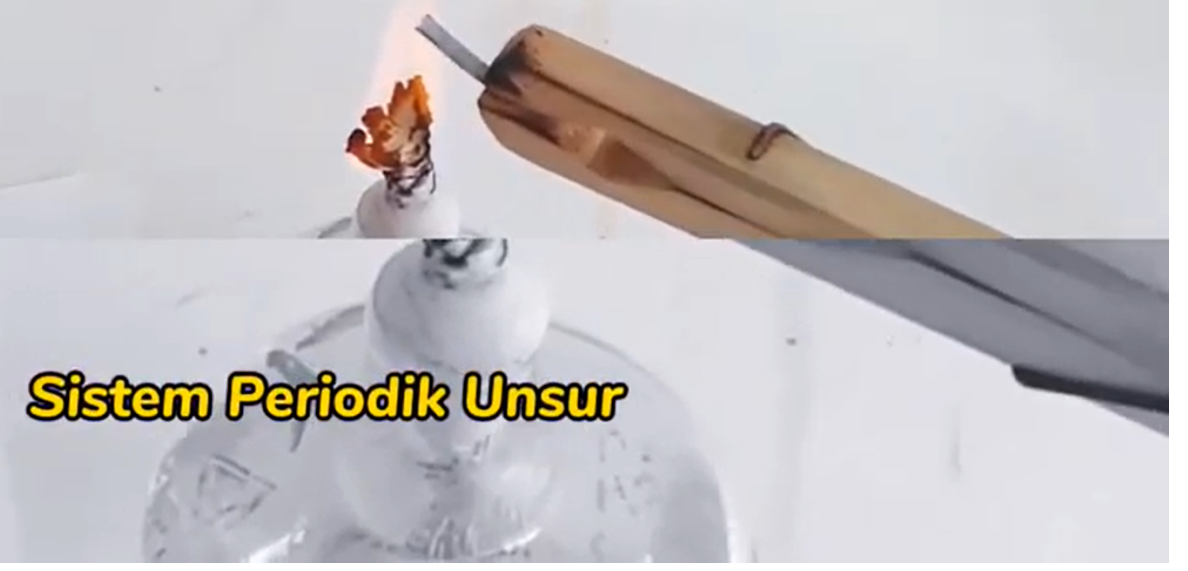

Gambar 3. Tampilan Layar Judul. 
Edukimia • 2022 • Vol. 4, No. 1

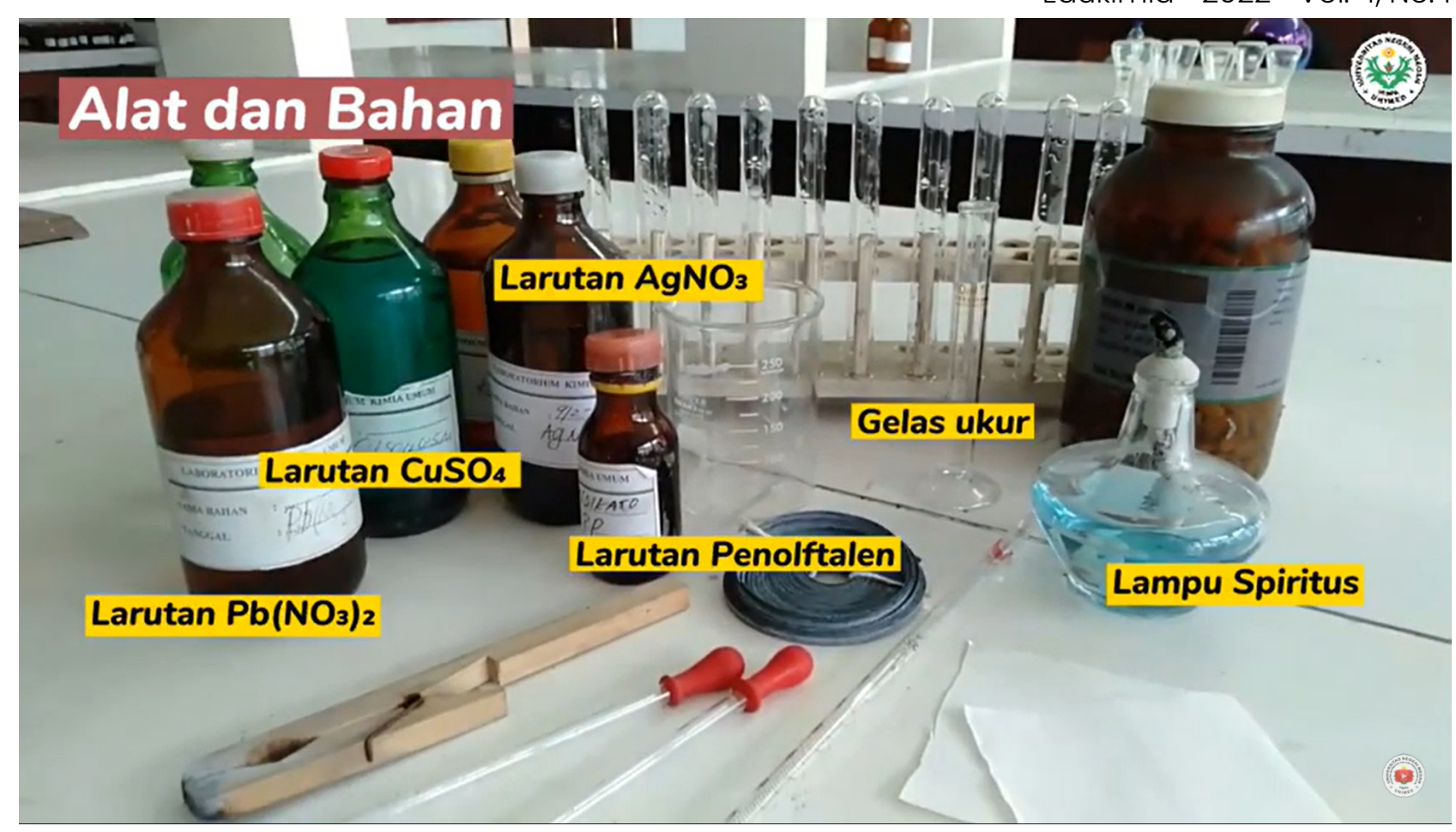

Gambar 4. Tampilan Layar Alat dan Bahan.

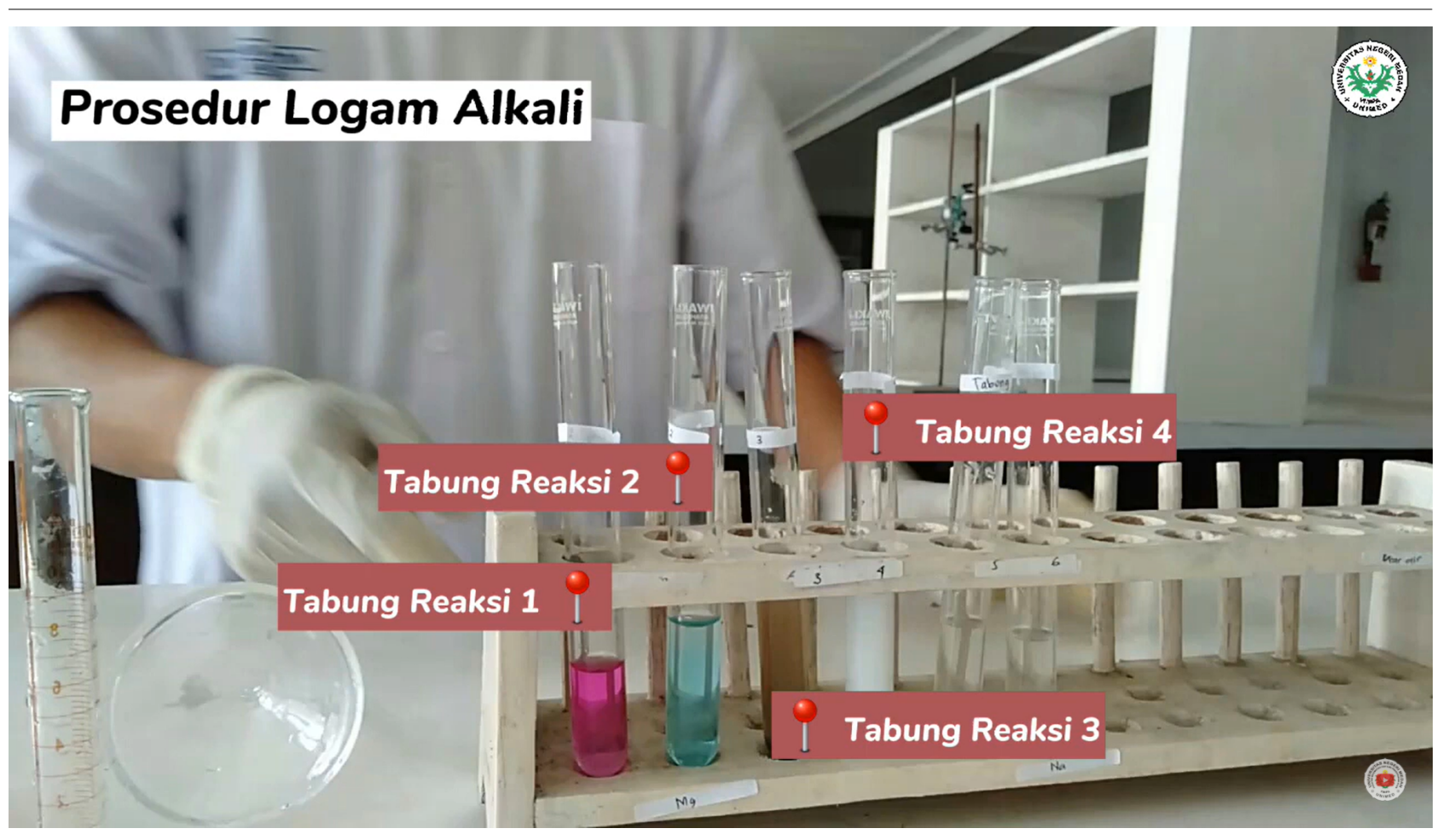

Gambar 5. Tampilan Layar Pengamatan Hasil Percobaan Sub-topik 1. 


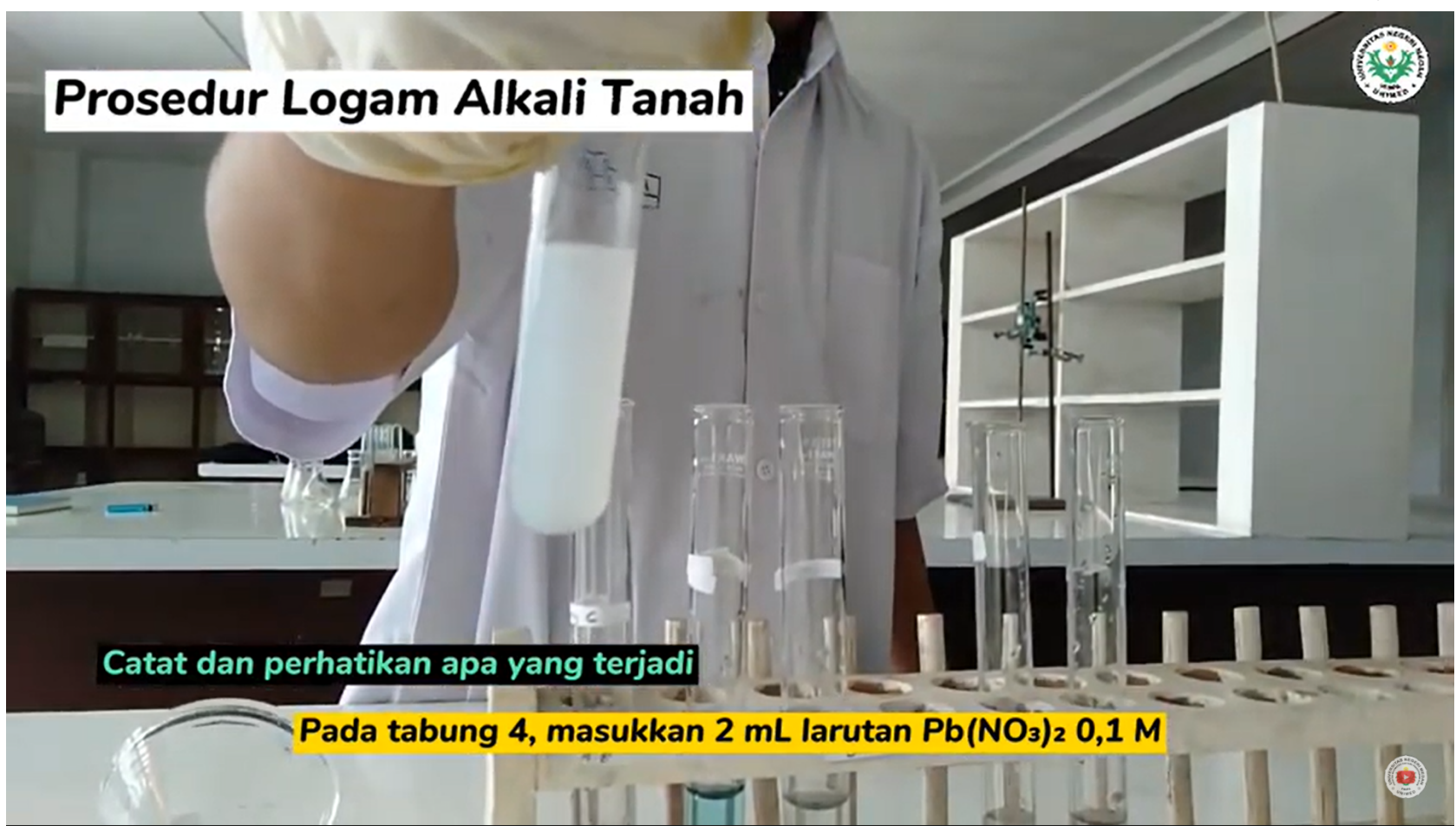

Gambar 6. Tampilan Layar Pengamatan Hasil Percobaan Sub-topik 2.

\section{SIMPULAN}

Hasil penelitian menunjukkan bahwa rata-rata skor validasi desain media dan validasi ahli materi oleh 3 orang dosen Jurusan Kimia FMIPA UNIMED menunjukkan angka 86,87\% dan 97,92\%, sehingga media praktikum kimia dasar berbasis video dinyatakan sangat valid. Respons dari 30 mahasiswa juga menunjukkan bahwa video yang dikembangkan sangat praktis dengan rata-rata skor $>90,00 \%$ dan telah sesuai dengan kebutuhan serta tujuan pembelajaran pada mata kuliah kimia dasar materi sistem periodik unsur.

\section{REFERENSI}

1. Khaeruman, Khery Y, Murdiono.

Pengembangan Laboratorium Virtual pada

Materi Larutan Elektrolit dan Non Elektrolit. J

Ilm IKIP Mataram. 2016;3(2):691-5.

2. Rokhim DA, Asrori MR, Widarti HR.

Pengembangan Virtual Laboratory Pada Praktikum Pemisahan Kimia Terintegrasi Telefon Pintar. JKTP J Kaji Teknol Pendidik. 2020;3(2):216-26.

3. Widahyu C. The Effectiveness of Using Video As a Learning Media Online Learning To Improve Students ' Learning Motivation and Creative Thinking At Home During the Covid-19 Pandemic. 2021;(January).

4. Yeni LF, Yokhebed. Pengembangan Virtual Laboratory Berbasis Multimedia Interaktif pada Matakuliah Microbiology Sub Materi Isolasi Bakteri. J Pendidik Mat dan IPA. 2015;6(1):57-67.

5. Erniwati, Eso R, Rahmia S. Penggunaan Media Praktikum Berbasis Video Dalam Pembelajaran Ipa-Fisika Untuk Meningkatkan Hasil Belajar Siswa Pada Materi Pokok Suhu Dan Perubahannya. J Sains dan Pendidik Fis.
2014;10(3):269-73.

6. Emda A. Laboratorium Sebagai Sarana Pembelajaran Kimia dalam Meningkatkan Pengetahuan dan Ketrampilan Kerja Ilmiah. Lantanida J. 2014;2(2).

7. Rahayu C, Eliyarti E. Deskripsi Efektivitas Kegiatan Praktikum Dalam Perkuliahan Kimia Dasar Mahasiswa Teknik. J Pendidik Sains Mat. 2019;7(2).

8. Epinur, Yusnidar. Pengembangan Laboratorium Virtual dengan Macromedia Flash 8 Materi Larutan Asam-Basa Untuk Kimia Dasar II. J Ind Soc Integ Chem. 2018;7(2):1-11.

9. Zakiah, Silalahi A, Muchtar Z. Pengembangan Penuntun Praktikum Tipe Discovery Dan Tipe Project Based Learning Pada Pembelajaran Elektrolit Dan Non Elektrolit Di SMA. J

Pendidik Kim. 2015;7(1):83-94.

10. Paristiowati M, N M, Rahma WA. Video Kimia Online Berbasis Pembelajaran Kontekstual Sebagai Alternatif Media Pada Materi Asam Basa di SMA. J Lentera Pendidik Pus Penelit LPPM UM METRO. 2017;2(1).

11. Harling VNV. Pengaruh Penggunaan Video Pembelajaran terhadap Kemampuan Berpikir Siswa pada Mata Pelajaran Kimia. EDUKATIF J ILMU Pendidik. 2021;3(5):3332-8.

12. Limatahu NA, Rahman NA, Abu SHN, Cipta I. Pengaruh Video Praktikum Dengan Modul Elektronik Terhadap Keterampilan Proses Pada Materi Stoikiometri Siswa Kelas X SMAN 2 Tidore Kepulauan. J Pendidik Kim. 2017;9(1):225-8.

13. Agustina A, Novita D. Pengembangan Media Pembelajaran Video untuk Melatih Kemampuan Memecahkan Masalah pada 
Materi Larutan Asam Basa. Unesa J Chem Educ. 2012;1(1):10-6.

14. Ardiman K, Tukan MB, Baunsele AB.

Pengembangan Video Pembelajaran Berbasis Praktikum Dalam Pembelajaran Daring Materi Titrasi Asam Basa Kelas XI SMAN 5 Pocoranaka. J Beta Kim. 2021;1(1):22-8.

15. Hendarto P, Maridi M, Prayitno BA. Validity of guided inquiry-based modules on digestive system to improve argumentation skill. J Pendidik Biol Indones. 2019;5(1).

16. Saraswati NLPA, Mertayasa INE. Pembelajaran Praktikum Kimia Pada Masa Pandemi Covid-19: Qualitative Content Analysis Kecenderungan pemanfaatan Teknologi Daring. Wahana Mat dan Sains J Mat Sains dan Pembelajarannya. 2020;14(2):144-61.

17. Dwiningsih K, Sukarmin, Muchlis, Rahma PT. Pengembangan Media Pembelajaran Kimia Menggunakan Media Laboratorium Virtual Berdasarkan Paradigma Pembelajaran Di Era Global. Kwangsan J Teknol Pendidik. 2018 Dec;6(2):156-76.

18. Dzikro AZT, Dwiningsih K. Kelayakan Media Pembelajaran Berbasis Laboratorium Virtual pada Sub Materi Kimia Unsur Periode Ketiga. Chem Educ Pract. 2021;4(2):160-70.

19. Annisa AR, Putra AP, Dharmono. Kepraktisan Media Pembelajaran Daya Antibakteri Ekstrak Buah Sawo Berbasis Macromedia Flash. Quantum J Inov Pendidik Sains. 2020;11(1):72-80.

20. Hidayah FF, Imaduddin M. Diskripsi Keterampilan Proses Sains Calon Guru Kimia Berbasis Inquiry Pada Praktikum Kimia Dasar. J Pendidik SAINS. 2015;3(1):8-12. 